\title{
REKONSTRUKSI HUKUM WARISAN DI INDONESIA PERSPEKTIF PLURALISME AGAMA
}

\author{
ABDUL MUFID \\ STAI Khozinatul Ulum Blora, Indonesia \\ nawalmiza@gmail.com
}

\begin{abstract}
Juridical, theological, and philosophical differences in religion are one of the challenges for someone to become an heir. On the other hand, empirically historical-sociological is not the case, because there are reasons (illat) or other related to different religions to get the inheritance of muslims who inherit using welfare factors. This research uses the normative legal research method. The author uses Gustav Radburch's theory of legal objectives governing justice, expediency, and legal certainty. Based on the results of the research found in the compilation of Islamic law is not available to the heirs who have been given apostasy. Religious differences as a barrier to inherit are specifically intended for heirs. So it can be concluded that muslim heirs can inherit the assets of nonmuslim heirs, but not vice versa. In this study, non-muslim heirs cannot inherit wealth from muslim heirs, in order to fulfill a sense of justice and respect, these non-muslim experts still obtain inheritance through mandatory wills which are processed through court determination. The will is obliged to be determined as a way out of giving the inheritance to non-muslim heirs because the heir has died, and there is no other way to be able to transfer the heir's assets to the non-muslim heirs.
\end{abstract}

Keywords: Non-Muslim inheritance, Inheritance, Compilation of Islamic Law

\begin{abstract}
Abstrak
Perbedaan yuridis, teologis dan filosofis agama adalah salah satu hambatan seseorang untuk menjadi pewaris. Di sisi lain, secara empiris historis-sosiologis tidak demikian, karena adanya alasan (illat) atau lainnya yang memungkinkan seseorang dari agama yang berbeda untuk mendapatkan warisan pewaris yang beragama Islam dengan mempertimbangkan faktor keadilan. Penelitian ini menggunakan metode penelitian hukum normatif. Penulis menggunakan teori tujuan hukum Gustav Radburch yang mencakup keadilan, kemanfaatan, dan kepastian hukum. Berdasarkan hasil penelitian ditemukan bahwa didalam kompilasi hukum Islam tidak mengatur kepada siapakah harta pewaris yang telah murtad dapat diberikan. Perbedaan agama sebagai penghalang untuk dapat mewarisi adalah khusus ditujukan kepada ahliwaris. Jadi dapat disimpulkan
\end{abstract}


bahwa ahliwaris muslim dapat mewarisi harta pewaris non muslim, tetapi tidak sebaliknya. Dalam penelitian ini, meskipun ahliwaris non muslim tidak dapat mewarisi harta dari pewaris muslim, demi memenuhi rasa keadilan dan rasa kemanusiaan, ahliwaris non muslim tersebut tetap mendapatkan harta warisan melalui wasiat wajibah yang prosesnya berdasarkan penetapan pengadilan. Wasiat wajibah ditetapkan sebagai jalan keluar dalam pemberian harta warisan kepada ahliwaris non muslim karena pewaris telah meninggal dunia, dan tidak ada cara lain untuk dapat mengalihkan harta pewaris kepada ahliwaris yang non muslim.

Kata Kunci: Waris non-muslim, Warisan, Kompilasi Hukum Islam

\section{PENDAHULUAN}

Perubahan sosial merupakan salah satu faktor munculnya konflik sosial yang terdiri dari masalah-masalah baru. Hal ini sesuai dengan apa yang dinyatakan Ian Robertson seorang sosiolog dari University of California Los Angeles "Social Change is The alteration of patterns of culture, Social structure and Social behaviours overtimes" perubahan sosial ialah perubahan pola budaya dalam masyarakat, struktur sosial dan perilaku masyarakat yang terjadi setiap waktu. ${ }^{1}$

Hukum Islam merupakan manifestasi dari wahyu tuhan ${ }^{2}$ yang wajib ditaati bagi seluruh umat Islam. Sumber-sumber hukum Islam antara lain Alquran, hadis, dan ijtihad. Di dalam hukum Islam lebih khusus pula mengatur tentang pembagian warisan bagi umat Islam. Hukum Islam, telah ada di Indonesia sejak masa pemerintahan kerajaan Islam, serta telah diratifikasi sebagai hukum positif bagi warga negara Indonesia yang beragama Islam. ${ }^{3}$ Saat ini, pengaturan mengenai hukum Islam telah dituangkan dalam Kompilasi Hukum Islam yang juga disebut KHI.

Pengertian hukum waris Islam menurut Amir Syarifudin adalah seperangkat peraturan tertulis berdasarkan wahyu Allah SWT dan sunnah Nabi Muhammad SAW tentang peralihan harta dari yang telah mati kepada yang masih hidup. ${ }^{4}$ Mengenai wasiat dan hibah diatur dalam 44 Pasal yang terdapat pada buku II Kompilasi Hukum Islam. Berkaitan dengan permasalahan yang dibahas oleh penulis yaitu pewarisan beda agama, yang dimaksud beda agama di sini adalah antara pewaris dan ahliwaris yang ditinggalkan saling berbeda agama. Misalnya, ahli waris beragama Islam sementara pewarisnya beragama Hindu, atau sebaliknya. Perbedaan agama tersebut disebabkan karena pewaris atau ahliwaris keluar dari agama Islam atau disebut juga murtad. Sedangkan yang dimaksud ahliwaris non muslim adalah seseorang yang secara nasab (keturunan) memiliki hubungan darah dengan pewaris dan lahir dalam perkawinan yang sah, namun

1 Rahmat Yudistiawan, Putusan-putusan Mahkamah Agung yang "Bertentngan dengan Nash, Jurnal Aqlam: Journal of Islam and Plurality, Vol. 3, No. 2, 2018, 249.

${ }^{2}$ David S.Powers, 'The Islamic Inheritance System A Socio Historikal Approach', 1993, 1.

3 S. Khosyi'ah, 'Analysis of Rules for Islamic Inheritance Law in Indonesia Using Hybrid Rule Based Learning', Journal Phisics, 3

${ }^{4}$ Amir Syarifuddin, Hukum Kewarisan Islam (Jakarta: Prenada Media, 2004). 
secara hukum waris Islam telah terputus hubungan kewarisannya dengan pewaris karena terhalang oleh perbedaan agama. Sehingga tidak berhak untuk menerima harta warisan. ${ }^{5}$

Hukum Islam merupakan salah satu aspek dari ajaran Islam yang menempati posisi penting dalam pandangan umat Islam, sebab dialah yang paling konkret dalam manifestasi Islam sebagai agama. Mustahil untuk memahami Islam tanpa memahami hukum Islam. ${ }^{6}$ Dalam Islam terdapat dimensi hukum yang disebut syarî'ah. Syarî'ah itu sendiri adalah ruang ekspresi terpenting dari agama yang menjadi rujukan bagi umat Islam. Syarî'ah juga merupakan objek refleksi utama yang bersumber dari al-Quran dan hadis. Syarî'ah menyajikan sebuah sistem nilai agama yang menjadi kerangka acuan untuk perilaku dan perbuatan setiap muslim.

Paling tidak ada empat langkah dalam menerapkan syarî'ah, yakni: 1). Langkah hermeneutis, 2). Langkah sosialisasi, 3). Langkah politik, dan 4). Langkahlangkah penegakan. ${ }^{7}$ Meskipun dalam praktiknya hukum Islam belum mampu memainkan peran penuh, namun masih memiliki arti dasar yang besar bagi penganutnya, yaitu membantu menciptakan nilai-nilai yang mengatur kehidupan mereka, setidaknya menentukan apa yang dianggap baik dan buruk. Seluruh pandangan dunia umat Islam ditentukan oleh tanggapan mereka masing-masing terhadap nilai-nilai itu yang pada gilirannya tentu akan mempengaruhi pilihan aspek kehidupan yang dianggap penting dan untuk cara mereka memperlakukan masa depan mereka sendiri. ${ }^{8}$

Sebagai konsekuensi dari negara yang berdasarkan hukum, hukum yang berlaku didukung oleh 3 (tiga) pilar utama, yaitu: 1). Institusi atau hukum yang andal sebagai penegak hukum, 2). Aturan hukum yang jelas, dan 3). Kesadaran hukum komunitas. ${ }^{9}$ Tiga pilar utama tersebut merupakan satu sistem yang saling berhubungan satu sama lain dan tidak bisa dipisahkan antara bagian yang satu dengan yang lain. Mulai dari kebijakan pembangunan nasional di bidang hukum tentang materi hukum, hukum aparatur, serta sarana dan prasarana hukum, budaya hukum dan hak asasi manusia. Tiga pilar tersebut juga merupakan unsur utama yang mendukung berlakunya supremasi hukum sebagai kebijakan pembangunan nasional sangat relevan dan mendesak. ${ }^{10}$

${ }^{5}$ Kartika Herenawati, I Nyoman Sujana, I Made Hendra Kusuma, Kedudukan Harta Warisan dari Pewaris Non Muslim dan Penerapan Wasiat Wajibah Bagi Ahli Waris Non Muslim (Analisis Penetapan Pengadilan Agama Bandung Nomor: 4/Pdt.P/2013/PA.Bdg/Tanggal 7 Maret 2013), DiH: Jurnal Ilmu Hukum, Vol. 16, No. 1, 2020, 26.

6Joseph Schacht, An Introduction to Islamic Law, Cet. 1 (London: The Clarendon Press, 1977), 1.

${ }^{7}$ Syamsul Anwar, Studi Hukum Islam Kontemporer, Cet. 1 (Yogyakarta: Cakrawala Press, 2006), 4-10.

${ }^{8}$ Abdurrahman Wahid, Muslim di Tengah Pergumulan, (Jakarta: LEPPENAS, 1981), 66.

${ }^{9}$ Mohammad Daud Ali, "Hukum Islam: Peradilan Agama dan Masalahnya," di dalam Yuhaya S. Praja (ed), Hukum Islam di Indonesia: Pemikiran dan Praktek, Cet. 1, (Bandung: Remaja Rosdakarya, 1991), 7.

${ }^{10}$ National Law Development Policy in State Policy Guidelines (TAP No.II / MPR / 1993) concerning legal matter, legal apparatus and legal facilities and infrastructure. It is also stated in 
Perkembangan bidang materi hukum termasuk materi hukum Islam diarahkan untuk merealisasikan sistem hukum nasional, seperti melayani kepentingan nasional dengan menyiapkan bahan hukum secara menyeluruh, terutama persiapan produk hukum baru atau pendirian hukum, pengembangan hukum, penyusunan kerangka hukum nasional, serta inventarisasi dan kompilasi unsur-unsur tatanan hukum yang berlaku untuk sistem hukum nasional yang berasal dari Pancasila dan Undang-undang Dasar 1945.

Ada dua cara dalam pengembangan hukum nasional, yaitu melalui pembentukan legislasi dan melalui hakim atau keputusan yurisprudensi. Pada saat ini dalam sistem hukum apa pun keputusan hakim (yurisprudensi) menempati tempat yang sangat penting, karena dalam keputusan hakim (jurisprudensi) seseorang dapat menemukan bentuk aturan hukum yang konkret. Selain itu sesuai dengan fungsi hakim, melalui yurisprudensi dimungkinkan penyesuaian aturan hukum dengan tuntutan perubahan, baik perubahan keadaan maupun perubahan rasa keadilan. Dalam bentuk adaptasi, interpretasi suatu aturan hukum mungkin tidak lagi memiliki arti yang efektif. Dalam keadaan seperti itu, sistem hukum suatu masyarakat atau negara akan lebih tercermin oleh serangkaian keputusan yudisial (yurisprudensi) dari pada serangkaian hukum dan peraturan.

Langkah selanjutnya yaitu dalam menerapkan syarî'ah adalah penegakan hukum. Dalam hukum Islam, perbedaan agama dalam bab warisan adalah salah satu kendala seseorang untuk menjadi pewaris (ahli waris yang mendapat bagian warisan). Dengan demikian non muslim tidak akan bisa mewarisi sebagai pewaris keluarga muslim mereka. Begitu juga sebaliknya, non muslim tidak akan bisa diwarisi oleh keluarganya yang muslim.

Dalam kehidupan pluralis bisa saja dalam sebuah keluarga terdiri dari anggota keluarga yang berbeda agama. Untuk memenuhi rasa keadilan sebagai salah satu prinsip hukum waris Islam, non muslim sebenarnya berhak mendapatkan bagian warisan dengan menggunakan siasat konstruksi wasiat (washiyyah wajibah) jika tidak ingin anggota keluarga terpecah belah.

Konstruksi kehendak merupakan cara alternatif terbaik untuk melengkapi sarana penyelesaian warisan bagi mereka yang tidak memiliki warisan, tetapi mereka memiliki hubungan dekat dengan pihak pewaris. Aspek hukum wasiat ini adalah keberadaan faktor penerima, seperti meningkatkan sistem atau kondisi ekonomi atas dasar kekerabatan, keberadaan yuridis faktor yang mencegahnya, tetapi di sisi lain dapat dikejar, dan adanya faktor keadilan.

Dalam memahami Kompilasi Hukum Islam, khususnya hukum warisan sebagai penegakan hukum yang diterapkan di Pengadilan Agama, ada interpretasi berbeda yang dibuat oleh hakim agama, yaitu menempatkan Kompilasi Hukum

GBHN 1989 drawn up and adopted by the MPR in the March 1998 general assembly in the field of law under the target subtitles relating to legal, apparatus and law enforcement materials, the development of legal facilities and infrastructure, legal culture and human rights. 
Islam, khususnya hukum waris dengan pendekatan teks, dogmatis, dan mandek sehingga tidak mampu menjawab permasalahan. Padahal masalah hukum Islam semakin dinamis dan kompleks. Selain itu, sebenarnya ada pendekatan lain dalam menafsirkan Kompilasi Hukum Islam terutama hukum waris dengan mengambil inti, esensi dan semangat yang terkandung di dalamnya, lalu mencoba menerapkannya sesuai dengan tuntutan tempat dan waktu. Ada tawaran pendekatan dalam paradigma lain, yaitu pemahaman teologis-filosofis dan historis-sosiologis. ${ }^{11}$

Untuk menjawab kesenjangan antara solen dan sein, antara hukum waris yang terkandung dalam Kompilasi Hukum Islam dan kenyataan melalui putusan atau ijtihad para hakim Pengadilan Agama yang memunculkan masalah di atas, kiranya penting untuk melakukan penelitian guna mendapatkan jawaban dalam menyelesaikan masalah dengan melakukan ijtihad pula. Berdasarkan latar belakang masalah di atas, dipandang perlu untuk melakukan studi tentang penegakan hukum keluarga Islam terkait warisan dalam pluralisme agama.

Terkait survey literatur terdahulu yang penulis temukan tentang kajian ini diantaranya dilakukan Hilma Yuniasti (2012) dengan judul pembagian wasiat wajibah kepada ahli waris yang berbeda agama (studi analisis putusan Pengadilan Agama perkara Nomor. 339/Pdt.G/2000/PAJB. Penelitian yang dilakukan Hilma Yuniasti bertujuan untuk mengetahui dasar pertimbangan hakim dalam putusan Nomor 339/Pdt.G/2000/PAJB serta untuk mengetahui pembagian wasiat wajibah kepada ahli waris beda agama.

Penelitian selanjutnya dilakukan oleh Ahya Burhani (2012) dengan judul status ahli waris non muslim dalam pembagian waris (analisis komparasi penetapan Nomor 42/P3HP/2007/PAJS dengan nomor 165/Pdt.p/2009/PJAS. Penelitian yang dilakukan Ahya Burhani ini bertujuan untuk mengetahui dasar pertimbangan hakim Pengadilan Agama Jakarta Selatan dalam menetapkan perkara komparasi No. 42/P3HP/2007/PAJS dengan No. 165/Pdt.p/2009/PJAS.

\section{METODE PENELITIAN}

Mulai dari deskripsi latar belakang masalah yang disebutkan di atas, maka masalah utama yang dibahas penulis dalam penelitian ini adalah rekonstruksi hukum keluarga Islam dibidang warisan. Penelitian ini menggunakan metode penelitian hukum normatif, spesifikasi dari penelitian ini adalah deskriptif analitis, sehingga tulisan yang dihasilkan diharapkan dapat memberikan kontribusi yang jelas, terperinci, dan sistematis, deskripsi perkembangan ilmu hukum Islam pada umumnya, dan khususnya pengetahuan hukum keluarga Islam tentang hukum waris, dilihat dari titik aplikasi (penegakan) hukum pewarisan hukum agama Islam

${ }^{11}$ Akh. Minhaji, Hukum Islam: Antara Sakralitas dan Profanitas (Perspektif Sejarah Sosial), (Yogyakarta: Universitas Islam Negeri Yogyakarta, 2004), 3-8. 
dengan melihat fakta dan peristiwa di balik perkara (perselisihan) yang harus terjadi terbukti di Pengadilan Agama.

Subjek penelitian ini adalah hukum perdata Islam khususnya hukum waris Islam yang merupakan kewenangan absolut Pengadilan Agama. Hukum waris Islam termasuk hukum keluarga Islam, bagaimana penegakannya dalam pluralisme agama dan kontribusinya terhadap hukum nasional dilihat dari hasil ijtihad hakim Pengadilan Agama tentang perkembangan hukum waris dalam Kompilasi Hukum Islam. Adapun analisis yang digunakan untuk memahami materi penelitian ini adalah kasus hukum, bukan dalam pengertian pendekatan netral yang terlepas dari konteks dan acara.

\section{HASIL DAN PEMBAHASAN \\ REALISASI REKONSTRUKSI DAN PERTIMBANGAN YUDISIAL HAKIM AGAMA TENTANG PENEGAKAN HUKUM WARISAN DALAM PLURALISME AGAMA DI INDONESIA}

Kasus yang terjadi di pengadilan agama jakarta pusat yaitu berkaitan dengan ahli warisnya terdiri dari anak-anak yang berbeda-beda agamanya. Keputusan Mahkamah Agung menyatakan bahwa anak-anak non-muslim (Nasrani) dilihat dari status hukumnya adalah bukan ahli waris, tetapi mereka berhak mendapatkan bagian dari warisan (orang tua) almarhum berdasarkan kehendak mustah yang setara dengan bagian anak perempuan pewaris ayah dan ibunya ".12

Secara riil kasus tersebut terjadi pada keluarga muslim terdiri dari suami dan istri (ayah-ibu) serta 6 (enam) anak yang terdiri dari 5 anak beragama Islam dan 1 (satu) anak (anak keempat) adalah non Islam (Kristen). Kedua orang tua memeluk Islam dengan meninggalkan mereka warisan dan 6 (enam) anak. Lima anakanaknya adalah muslim dan 1 (satu) adalah Kristen. Warisan tidak pernah didistribusikan kepada ahli waris yang Kristen. Kemudian salah satu anak yang menjadi ahli waris mengajukan gugatan kepada Pengadilan Agama dengan dalih bahwa atas kesepakatan saudara-saudaranya yang menghendaki pembagian warisan berdasar hukum Islam, sehingga dia tidak diberi bagian warisan dikarenakan non muslim.

Tergugat berdiri di hadapan hakim seraya mengklaim bahwa salah satu dari saudaranya yang non-muslim tidak berhak untuk mewarisi harta peninggalan milik orang tuanya yang memeluk Islam. Di persidangan Pengadilan Agama, antara penggugat dan tergugat tutut hadir dalam persidangan, dan hakim memberikan jawaban yang membenarkan argumen tergugat. Saat sidang selanjutnya, yaitu sidang kedua, pihak penggugat (anak yang non muslim) tidak mau menghadiri

12 Putusan Pengadilan Agama Jakarta Pusat: No. 377/Pdt.G/1993/PA-Jk. Tanggal 4 Nopember 1993 M, bertepatan dengan tanggal 19 JumadilAwal 1414 H. Jo. Putusan Pengadilan Tinggi Agama Jakarta: No.14/Pdt.G/1994/PTA-JK, tanggal 25 Oktober 1994 M, bertepatan dengan tanggal 20Jumadil Awal 1415 H. Jo. Putusan Mahkamah Agung RI: No. 368.K/AG/1995, tanggal 16 Juni 1998. 
persidangan di Pengadilan Agama. Pihak penggugat memberikan alasan ketidakhadirannya melalui surat jawaban, bahwa pasal 1, 2, 3 UU No. 7 Tahun 1989 Pengadilan Agama adalah forum keadilan bagi orang-orang yang beragama Islam. Karena penggugat memeluk agama Kristen, maka ia keberatan untuk diadili oleh Pengadilan Agama yang bukan forum keadilan bagi orang Kristen, melainkan seharusnya adalah Pengadilan Negeri. Dalam hal itu ia berpendapat bahwa klaim keterhalangan warisan di Pengadilan Agama oleh saudara-saudaranya yang muslim adalah karena ada niat untuk mengisolasi atau menghalangi warisan dari ayah-ibunya.

Dalam hal ini Pengadilan Agama mempertimbangkan dan memutuskan bahwa menurut pasal 171 (c) Pengadilan Agama percaya bahwa peserta dari tergugat II adalah Kristen, maka menurut hukum Islam, tidak menjadi pewaris ayahnya yang sudah meninggal yang beragama Islam." Padahal menurut pasal 176 dan pasal 180 Kompilasi Hukum Islam, ahli waris almarhum ayah adalah anakanak yang Islam, dengan besarnya masing-masing memperhatikan QS. An-Nisa'. 4: (11).

Pengadilan Tinggi Agama berbeda dalam menangani kasus di atas yang telah diputuskan oleh Pengadilan Agama sebelumnya. Karena penggugat adalah Kristen yang menolak putusan Pengadilan Agama dan dia mengajukan banding. Keputusan Pengadilan Tinggi Agama tidak sepakat dengan keputusan Pengadilan Agama, maka perlu untuk memberikan pertimbangan tersendiri, dimana penggugat (anak yang non muslim) juga bisa mendapatkan bagian dari warisan yang ditinggalkan oleh almarhum. Berbeda dengan keputusan Pengadilan Agama yang menyatakan bahwa mereka yang mendapat bagian dari harta warisan pewaris hanya anak yang muslim saja.

Pengadilan Tinggi Agama Jakarta pada dasarnya mempertimbangkan hal-hal sebagai berikut: "Menilai, mengembalikan putusan Pengadilan Agama Jakarta, dan mengadili dirinya sendiri, dengan menolak pengecualian responden II (anak non muslim) dalam masalah pokok pemberian sebagian gugatan, memberikan pewaris sah dari almarhum adalah anak-anaknya muslim. Anak non-Muslim berhak mendapatkan bagian dari warisan almarhum, berdasarkan "kehendak mustah" untuk $3 / 4$ (tiga perempat) anak perempuan dari pewaris almarhum.

Mahkamah Agung Republik Indonesia melihat kasus di atas dengan pandangan yang berbeda dari putusan Pengadilan Agama dan Pengadilan Tinggi Agama. Penggugat dan tergugat sama-sama menolak keputusan Pengadilan Tinggi Agama di atas dan mengajukan kasasi dengan mengajukan beberapa keberatan dalam memori bandingnya. Semua banding dilakukan oleh pemohon banding kasasi dinyatakan tidak layak oleh Mahkamah Agung Majelis karena keberatan mengenai penilaian hasil bukti penghargaan atas suatu fakta yang tidak dapat dipertimbangkan dalam banding kasasi. Meskipun demikian, menurut Mahkamah Agung Majelis keputusan Pengadilan Tinggi Agama harus diperbaiki, karena 
bagian "mustah" untuk terdakwa II (anak non-Muslim) seharusnya sama dengan bagian warisan perempuan itu. Dengan demikian, putusan Mahkamah Agung di atas dapat dijelaskan bahwa lima anak muslim ditunjuk sebagai ahli waris dari ayahnya dan almarhum ibunya dan setiap anak memiliki bagian dari warisan kedua orang tua. Bagian anak laki-laki adalah dua bagian dari anak perempuan. Sementara anak perempuan non-Muslim (Nasrani) status hukumnya bukan ahli waris, tetapi dia berhak atas bagian dari harta orangtuanya yang telah meninggal berdasarkan "kehendak mustah" yang setara dengan perempuan pewaris ayah dan ibunya yang sudah meninggal.

Putusan Mahkamah Agung di atas berbeda dari norma hukum yang terkandung dalam Alquran, hadis, dan Kompilasi Hukum Islam. Kesepakatan mayoritas ulama mengatakan bahwa berbeda agama itu menjadi pewaris dan diwarisi jika ahli waris dan yang diwarisi salah satunya adalah muslim dan yang lainnya tidak. Dasar hukumnya adalah QS. An-Nisa'.4: (141) yang berbunyi: “Dan Allah sekali-kali tidak akan memberi jalan kepada orang-orang kafir untuk memusnahkan orang-orang yang beriman." Selanjutnya, QS. Al-Maidah. 5: (48) yang menjelaskan bahwa "untuk tiap-tiap umat di antara kamu, Kami berikan aturan dan jalan yang terang." Demikianlah Imam Malik dan Ahmad mengemukakan pendapat yang berbeda agama yang bukan Islam tetap merupakan reli yang diwariskan. ${ }^{13}$

Dasar hukum lain diungkapkan dalam sunah Nabi yang statusnya adalah Muttafaq Alaih, diriwayatkan oleh Imam Bukhari dan Muslim, keduanya menyatakan: "Muslim tidak mewarisi milik orang-orang kafir, dan orang-orang kafir tidak mewarisi harta umat Islam (Muttafaq Alaih) ". Dasar hukum dalam Kompilasi Hukum Islam bahwa perbedaan agama merupakan salah satu dari seseorang membesarkan untuk menjadi ahli waris, dinyatakan dalam pasal 171 huruf (c): "Ahli waris adalah orang yang pada saat meninggal dunia mempunyai hubungan darah atau hubungan perkawinan dengan pewaris, beragama Islam dan tidak terhalang karena hukum untuk menjadi ahli waris."

Pertimbangan hukum putusan hakim (jurisprudensi) disebutkan di atas secara ilmiah berdasarkan pada ajaran dalam al-Quran yang telah dijelaskan untuk pengakuan kebebasan beragama dan kemajemukan. Al-Quran menekankan kebebasan beragama dan berkeyakinan untuk toleransi dan penghormatan terhadap agama lain ke dalam ajaran Islam. Al-Quran mengajarkan gagasan pluralitas agama, bukan berarti secara langsung mengakui kebenaran semua agama dalam bentuk nyata di Indonesia dalam kehidupan sehari-hari. Ajaran penegasan agama menekankan dasar gagasan bahwa semua agama diberi kebebasan untuk hidup, dengan resiko yang akan dikenakan kepada pengikut agama masing-masing. Adapun prinsip-prinsip mendasar yang ditawarkan oleh alQuran dalam hubungan antar agama-agama setidaknya ada tiga prinsip dasar yang

${ }^{13}$ Ahmad Rofiq, Fiqh Mawaris, Cet. Keempat (Jakarta: PT. Raja Grafindo Persada, 2002), 38. 
menjadi rujukan di Indonesia dalam rangka membina hubungan antara muslim dan non muslim, yaitu kemurnian tauhid, persamaan, keadilan dan perdamaian.

\section{METODE DAN PERAN HAKIM AGAMA DALAM PENEGAKAN HUKUM KEWARISAN DAN PLURALISME AGAMA}

Untuk menegakkan hukum dan keadilan, tugas utama hakim pengadilan agama adalah berwenang untuk memeriksa, memutuskan, dan menyelesaikan kasus antar umat Islam, yang salah satunya adalah warisan. Seorang hakim dalam membuat keputusan harus tetap beralasan dan berada dalam koridor hukum. Sedangkan keadilan, merupakan implikasi dari keberadaan penegakan hukum. Seorang hakim dalam menjalankan tugas seharusnya tidak diskriminatif.

Dari posisi kasus di atas, maka isi keputusan Mahkamah Agung yaitu warisan dalam Islam meliputi anak-anak ahli waris yang terdiri dari Islam dan non-Islam. Putusan pengadilan Mahkamah Agung menyatakan bahwa putra-putra dari status hukum non-Muslim (Nasrani) bukan ahli waris, tetapi ia berhak berbagi harta warisan almarhum orang tua atas dasar "kehendak mustah" yang sama dengan bagian dari perempuan ahli waris ayah yang telah meninggal. Putusan pengadilan Mahkamah Agung Republik Indonesia adalah bertentangan dengan Kompilasi Hukum Islam (KHI) yang menyatakan bahwa: "Ahli waris adalah orang yang pada saat meninggal dunia mempunyai hubungan darah atau hubungan perkawinan dengan pewaris, beragama Islam dan tidak terhalang karena hukum untuk menjadi ahli waris." (Pasal 171 (c).

Melihat posisi kasus di atas, ada perbedaan antara norma-norma hukum yang terkandung dalam Kompilasi Hukum Islam dengan norma hukum yang terkandung dalam putusan Mahkamah Agung sebagai kulminasi dari penilaian hukum dan keadilan tentang sengketa warisan hukum Islam. Memang hal seperti itu dimungkinkan terjadi, karena hukum Islam memiliki hukum dasar yang merupakan sumber ketiga hukum Islam, yaitu al-ra'yu (logika) dengan metode ijtihad yang dapat menjawab tantangan zaman dan dapat memenuhi harapan dengan tetap menjaga semangat (spirit) dari Islam, karena diantara karakter hukum Islam adalah harakah atau dinamis, dimana hukum Islam memiliki kemampuan untuk bergerak dan berkembang, memiliki kekuatan hidup dan juga bisa menyesuaikan diri sesuai dengan perkembangan zaman. Terdapat terobosan baru perkembangan hukum warisan dalam Kompilasi Hukum Islam yaitu memberikan bagian warisan kepada anak-anak non-muslim yang belum pernah dilakukan atau dikenal dalam praktik di Pengadilan Agama karena berbeda dengan al-Quran, hadis, dan Kompilasi Hukum Islam.

Metode ijtihad hakim Pengadilan Agama dalam memutuskan posisi kasus di atas tidak dapat dilepaskan dengan teori maqâshid al-syarî'ah, yaitu gaya iluminasi ta'lili dengan metode istihsan dan gaya metode ta'lili dalam konsep maslahat. Selain itu berkaitan dengan tugas hakim harus memutuskan kasus yang diajukan 
kepadanya, lalu dia mengajukan permohonan hukum dalam kasus-kasus tertentu, maka bentuk ijtihadnya disebut ijtihad tatbiqi, juga ijtihad istinbati.

Istihsan artinya mengambil hal-hal baik. Menurut Abdul Wahab Khalaf, istihsan adalah berpindahnya seorang mujtahid dari ketentuan qiyas jali (yang jelas) kepada ketentuan qiyas khafi (yang samar), atau ketentuan yang kulli (umum) kepada ketentuan yang sifatnya istisna'i (pengecualian), karena menurut pandangan mujtahid itu adalah dalil (alasan) yang lebih kuat yang menghendaki perpindahan tersebut. ${ }^{14}$ Selain itu, Mahkamah Agung dalam memutuskan posisi kasus tersebut menggunakan pola penalaran istislahi dengan metode maslahat. Dengan demikian, anak-anak non-muslim yang menjadi ahli waris dapat mewarisi warisan dari muslim dengan alasan watuqsitu ilaihim (dan bersikap adil kepada mereka) berarti untuk memberikan (qistan) dari kekayaan kepada mereka (nonmuslim) untuk mempertahankan hubungan baik yang disebut maslahat.

Peran ijtihad hakim agama pada penegakan hukum keluarga Islam di bidang pewarisan dalam pluralisme agama adalah lembaga hukum yang menegakkan kepastian hukum, serta institusi sosial yang memfasilitasi dinamika perkembangan sosial dari aspek hukum yang menghasilkan putusan hakim. Pengadilan Agama memiliki nilai keadilan (aspek filosofis) dan nilai manfaat (aspek sosiologis). Dari sinilah penemuan hukum mutlak diperlukan, apalagi pengembangan kehidupan (termasuk perkembangan hukum keluarga Islam di Indonesia) dalam konteks kehidupan berbangsa dan bernegara dalam pluralisme agama.

\section{KONTRIBUSI IJTIHAD HAKIM AGAMA PADA PENEGAKAN HUKUM WARISAN DALAM PLURALISME AGAMA.}

Keputusan Mahkamah Agung yang menyatakan bahwa anak yang nonmuslim (Nasrani) dan berstatus legal bukanlah termasuk ahli waris, tetapi mereka berhak untuk berbagi di properti orang tua mereka (warisan muslim) atas dasar kehendak wajib, sebagai perempuan pewaris ayah dan ibunya. Putusan Mahkamah Agung dapat ditarik oleh aturan hukum, yaitu bahwa dalam kaitannya dengan warisan Islam, perbedaan agama bukanlah salah satu hambatan seseorang untuk mendapatkan bagian dari warisan ahli waris yang beragama Islam. Untuk memenuhi rasa keadilan sebagai salah satu prinsip-prinsip hukum waris Islam, non-muslim berhak untuk mendapatkan bagian dari harta warisan ahli waris (muslim) dengan menggunakan konstruksi hukum kehendak yaitu kehendak mustah.

Ada dua cara dalam pengembangan hukum nasional, yaitu melalui pembentukan legislasi dan melalui keputusan yudisial (yurisprudensi). Putusan hakim Pengadilan Agama menempati tempat yang sangat penting, karena dalam penghakiman (yurisprudensi) seseorang dapat menemukan bentuk norma hukum

${ }^{14}$ Abdul Wahab Khalaf, Ilmu Ushul al-Fiqh (Kairo: Dar al-Kuwaitiyyah, 1968), 79. 
yang konkret, disamping ada izin menyesuaikan aturan hukum dengan tuntutan perubahan, baik perubahan keadaan dan perubahan rasa keadilan.

Mempertimbangkan posisi kasus dalam tulisan ini, ada kontribusi hakim Pengadilan Agama tentang pengembangan hukum waris dalam Kompilasi Hukum Islam dengan hukum nasional, yaitu anak biologis non muslim (Nasrani) berhak mendapatkan bagian dari warisan kedua orang berdasarkan kehendak wajib, yang sama dengan bagian dari anak perempuan ayah dan ibu pewaris. Keputusan hakim tentang pengembangan hukum waris Islam dalam Kompilasi Hukum Islam dapat ditafsirkan dalam hukum nasional. Keputusan itu oleh Pengadilan Agama digali dari ajaran atau hukum Islam atau penerapan ajaran atau hukum Islam akan menjelma dalam bentuk dari prinsip atau prinsip hukum yang berasal dari ajaran atau prinsip dan pesan nilai-nilai agama, yang merupakan cara berpikir masyarakat dan bangsa Indonesia.

Keputusan Mahkamah Agung adalah pembentukan aturan hukum yang berasal dari ajaran Islam dan hukum sebagai bagian dari sistem nasional yang legal. Selain itu dalam keputusan (yurisprudensi), kelahiran atau menyesuaikan doktrin (hukum) sesuai dengan ajaran Islam menjadi doktrin dari sistem hukum nasional. Dengan demikian tidak ada dualisme diantara keduanya hukum Islam dan hukum nasional karena sepenuhnya tercermin dalam penilaian (jurisprudensi), dan produk hukum Islam yang menjadi milik dan dinikmati oleh muslim Indonesia, tetapi juga dapat dimiliki dan dinikmati oleh agama-agama lain selain Islam.

Dengan demikian, refleksi sinergi tercermin dalam perumusan hukum Islam dan penerapannya (aplikasi atau vonis) dari integrasi hukum yang melahirkan antara gagasan agama (yang hanya milik umat Islam) dengan gagasan kebangsaan (yang dimiliki publik atau seluruh bangsa). Dengan demikian keberadaan hukum Islam adalah sebagai bagian tidak terpisahkan dari kesadaran komunitas muslim Indonesia tentang hukum dan keadilan yang jelas keberadaan atau eksistensi dalam kerangka hukum nasional.

Kontribusi hukum Islam melalui penilaian (yurisprudensi) adalah instrumen lain dalam pembentukan hukum. Undang-undang Mahkamah Agung mewajibkan hakim untuk menemukan hukum yang tepat dalam menentukan keputusan. Penting bagi hakim untuk memberikan keadilan sebagaimana layaknya.

Dari analisis posisi kasus warisan yang telah dijelaskan, hukum Islam (Kompilasi Hukum Islam) melalui putusan Pengadilan Agama dapat disumbangkan kepada hukum waris yang berlaku secara nasional juga yang saat ini belum memiliki unifikasi dan kodifikasi yang baik. Teori transformasi dan teori penemuan hukum digunakan sebagai pisau analisis bahwa yurisprudensi Pengadilan Agama bisa dijadikan norma hukum yang dapat disumbangkan kepada hukum nasional yang tidak membedakan asal usul agama setiap masyarakat Indonesia. 


\section{PENUTUP}

Berdasarkan analisis kualitatif dengan menggunakan pendekatan yuridis normatif dan studi paradigma konstruktivisme, penelitian ini menyimpulkan Pertama, bentuk rekonstruksi dan pertimbangan hukum hakim Pengadilan Agama tentang penegakan hukum waris di Indonesia dalam konteks pluralisme agama adalah: (1) Realisasi rekonstruksi adalah anak kandung (perempuan) yang bukan muslim (Kristen) dari status hukum mereka bukan pewaris, tetapi ia berhak mendapat bagian harta warisan berdasarkan wasiat wajib yang bagiannya sama dengan bagian anak perempuan (lainnya) dari almarhum ayah ibu, dan (2) untuk pertimbangan hukum dalam vonis yang ada di kehidupan serba tidak menutup kemungkinan dalam keluarga terdiri dari anggota keluarga dari berbagai agama. Untuk memenuhi rasa keadilan sebagai salah satu prinsip hukum waris Islam, nonmuslim dari warisan ahli waris Muslim dengan konstruksi hukum kehendak mustah. Dalam QS. Almumtahanah, 60: (8) al-Qurtubi menafsirkan kata watuqsitu ilaihim (dan bersikap adil kepada mereka), menyarankan bahwa ayat tersebut juga dapat diartikan sebagai pemberi pengeluaran (infaq) terhadap non-muslim yang hidup di tengah-tengah keluarga muslim. Menurutnya, perbedaan agama tidak menghalangi hak mereka untuk mencari nafkah.

Kedua, metode dan peran hakim hakim ijtihad Agama Pengadilan tentang penegakan hukum waris hukum keluarga Islam di Indonesia bidang pluralisme agama adalah: (1) maqâsid al-syarî'ah dengan metode istihsan dengan mempertimbangkan efek positif dan negatif dari penerapan hukum (al-nazar fi alma'alat) di samping metode penerima manfaat dengan corak penelaran istislahi, dan (2) itu peran hakim pengadilan agama mendesak ijtihad mana Keadilan Agama adalah lembaga yang dinamis, menafsirkan teks-teks hukum (Kompilasi Islam Hukum) dalam konteks masyarakat dan perubahan. Pengadilan Agama adalah tidak hanya bangunan yuridis, tetapi terkait dengan begitu banyak sosiologis komponen bangunan, yaitu, sebagai lembaga hukum dengan budaya akar yang harus responsif terhadap dinamika hukumnya orang-orang.

Ketiga, kontribusi terhadap hukum nasional dari ijtihad hakim Pengadilan Agama tentang penegakan hukum keluarga Islam di bidang pewarisan hukum dalam pluralisme agama adalah perbedaan agama bukan salah satunya penghalang seseorang untuk mendapatkan bagian dari warisan ahli waris (muslim). Untuk memenuhi rasa keadilan sebagai salah satu prinsip hukum waris Islam, nonMuslim berhak mendapatkan bagian dari warisan ahli waris (muslim) dengan menggunakan konstruksi hukum kehendak, yaitu: "kehendak mustah". Adapun kontribusi menurut hukum nasional adalah anak kandung (perempuan) yang bukan muslim (Kristen) yang status hukumnya bukan sebagai pewaris, tetapi ia adalah berhak atas bagian warisan yang menjadi dasar kedua orang tua (Muslim 
Waris) dipinjam, yang bagiannya sama dengan bagian anak (wanita) pewaris ayah dan ibunya yang telah meninggal.

\section{DAFTAR PUSTAKA}

Khallaf, Abdul Wahab. Ilmu Ushul al-Fiqh. Kairo: Dar al-Kuwaitiyyah. 1968.

Wahid, Abdurrahman. Muslim di Tengah Pergumulan, Jakarta: LEPPENAS. 1981.

Daud Ali, Mohammad. "Hukum Islam: Peradilan Agama dan Masalahnya," di dalam

Yuhaya S. Praja (ed). Hukum Islam di Indonesia: Pemikiran dan Praktek, Cet. 1, Bandung: Remaja Rosdakarya. 1991.

Rofiq, Ahmad. Fiqh Mawaris. Cet. ke-4, Jakarta: PT. Raja Grafindo Persada. 2002.

Minhaji, Akh. Hukum Islam: Antara Sakralitas dan Profanitas (Perspektif Sejarah

Sosial). Yogyakarta: Universitas Islam Negeri Yogyakarta. 2004.

Syarifuddin, Amir. Hukum Kewarisan Islam. Jakarta: Prenada Media. 2004.

Powers, David S. The Islamic Inheritance System A Socio Historikal Approach .1993.

Schacht, Joseph. An Introduction to Islamic Law. Cet. 1. London: The Clarendon Press. 1977.

Herenawati, Kartika. Sujana, I Nyoman and Hendra Kusuma, I Made. Kedudukan Harta Warisan dari Pewaris Non Muslim dan Penerapan Wasiat Wajibah Bagi Ahli Waris Non Muslim (Analisis Penetapan Pengadilan Agama Bandung Nomor: 4/Pdt.P/2013/PA.Bdg/Tanggal 7 Maret 2013), DiH: Jurnal Ilmu Hukum, Volume 16, Nomor 1, 2020.

Rahmat Yudistiawan. Putusan-putusan Mahkamah Agung yang "Bertentngan dengan Nash, Jurnal Aqlam: Journal of Islam and Plurality. Volume 3, Nomor 2, 2018.

Ronny Haniyo Soemitro. Metodologi Peneltian Hukum. Cet. 1, Jakarta: Ghalia Indonesia. 1982.

S. Khosyi'ah. Analysis of Rules for Islamic Inheritance Law in Indonesia Using Hybrid Rule Based Learning. Journal Phisics.

Syamsul Anwar. Studi Hukum Islam Kontemporer. Cet. 1, Yogyakarta: Cakrawala Press. 2006. 